\title{
UPAYA MENINGKATKAN HASIL BELAJAR IPS DENGAN MENGGUNAKAN METODE PEMBELAJARAN LEARNING START WITH A QUESTION PADA PESERTA DIDIK KELAS VII-A MTS MIFTAHUL JANNAH PALANGKA RAYA
}

\author{
Oleh \\ Tarwiyah,* Setyo Wibowo**
}

\begin{abstract}
This study aims to find out: (1) How to increase the learning activities of students when using the learning method of Learning Start With a Question (LSQ) on social studies learning in class VII-A MTs Miftahu Jannah Palangka Raya, (2) Is there an increase in social studies learning outcomes students after using the learning method Learning Start With a Question (LSQ) in class VII-A MTs Miftahul Jannah Palangka Raya. The research method used in this study is the Classroom Action Research (CAR) method. The research subjects were class VII-A MTs Miftahul Jannah Palangka Raya with subjects as many as 24 students. Data collection techniques in this study used observation and tests. Data analysis techniques are based on the results of each learning process cycle. The results of this study are: (1) an increase in learning activities when using the Learning Start With a Question (LSQ) learning method for students of class VII-A MTs Miftahul Jannah Palangka Raya Tahun to be better, namely the score of learning activities of students in the first cycle Individuals have 15 students who get a score of $\geq 75$, and 9 students who score $<75$ with an average score of 2.67 . Scores of learning activities of students in the second cycle there were 23 students who obtained a score of $\geq 75$, and 1 student who scored $<75$ with an average of 3.86 , so that the learning activities of students in the second cycle had been categorized as good or already achieving indicators of success, (2) There is an increase in social studies learning outcomes after using the Learning Start With a Question (LSQ) learning method for students of class VII-A MTs Miftahul Jannah Palangka Raya. This can be seen from the data on student learning outcomes during the pre test obtaining an average value of 30.20 with completeness in classical $0 \%$. Post test cycle I obtained an average score of 78.95 with completeness in classical $62.5 \%$, and in cycle II increased with an average value of 90.41 with classical completeness $95.83 \%$.
\end{abstract}

Keywords: Learning Method Start with a Question (LSQ), Social Studies Learning Outcomes

\begin{abstract}
ABSTRAK
Penelitian ini bertujuan untuk mengetahui: (1) Bagaimana peningkatan aktivitas belajar peserta didik ketika menggunakan metode pembelajaran Learning Start With a Question (LSQ) pada pembebelajaran IPS di kelas VII-A MTs Miftahu Jannah Palangka Raya, (2) Apakah ada peningkatan hasil IPS belajar peserta didik setelah menggunakan metode pembelajaran Learning Start With a Question (LSQ) di kelas VII-A MTs Miftahul Jannah Palangka Raya. Metode penelitian yang digunakan dalam penelitian ini adalah metode Penelitian Tindakan Kelas (PTK). Subjek penelitian adalah kelas VII-A MTs Miftahul Jannah Palangka Raya dengan subjek sebanyak 24 orang peserta didik. Teknik pengumpulan data pada penelitian ini menggunakan
\end{abstract}

Tarwiyah* Mahasiswa FKIP UM Palangkaaraya

Setyo Wibowo** Dosen Universitas Muhammadiyah Palangkaraya 
observasi dan tes. Tehnik analisis data didasarkan pada hasil siklus tiap proses pembelajaran. Hasil penelitian ini yaitu: (1) peningkatan aktivitas belajar ketika menggunakan metode pembelajaran Learning Start With a Question (LSQ) pada peserta didik kelas VII-A MTs Miftahul Jannah Palangka Raya Tahun menjadi lebih baik, yaitu skor aktivitas belajar peserta didik pada siklus I secara individual teradapat 15 orang peserta didik yang memperoleh skor $\geq 75$, dan 9 orang peserta didik yang memperoleh skor $<75$ dengan skor rata-rata 2,67. Skor aktivitas belajar peserta didik pada siklus II terdapat 23 orang peserta didik yang memperoleh skor $\geq 75$, dan 1 orang peserta didik yang memperoleh skor $<75$ dengan rata-rata 3,86, sehingga aktivitas belajar peserta didik pada siklus II sudah dikategorikan baik atau telah mencapai indikator keberhasilan, (2) Ada peningkatan hasil belajar IPS setelah menggunakan metode pembelajaran Learning Start With a Question (LSQ) pada peserta didik kelas VII-A MTs Miftahul Jannah Palangka Raya. Hal ini terlihat dari data hasil belajar peserta didik pada saat pre test memperoleh nilai rata-rata 30,20 dengan ketuntasan secara klasikal $0 \%$. Post test siklus I memperoleh nilai rata-rata 78,95 dengan ketuntasan secara klasikal 62,5\%, dan pada siklus II meningkat dengan nilai rata-rata 90,41 dengan ketuntasan secara klasikal 95,83 \%.

Kata Kunci: Metode Learning Start with a Question (LSQ), Hasil Belajar IPS

\section{PENDAHULUAN}

Pendidikan merupakan suatu proses belajar yang berlangsung seumur hidup atau sepanjang hayat. Pendidikan juga merupakan suatu upaya untuk meningkatkan kualitas sumber daya manusia baik fisik, mental maupun spritual. Perkembangan ilmu pengetahuan yang sangat pesat membawa dampak positif dalam keinginan dan upaya masyarakat untuk meningkatkan pengetahuan diri agar tidak tertinggal dalam kemajuan ilmu pengetahuan dan pendidikan.

Pendidikan adalah suatu proses pelatihan dan pengajaran ,terutama diperuntukkan kepada anak-anak dan remaja, baik disekolah-sekolah maupun di kampus-kampus, dengan tujuan memberikan pengetahuan dan mengembangkan keterampilanketerampilan. Pendidikan pada dasarnya merupakan usaha yang sadar dan terencana untuk mewujudkan suasana efektif dan efisien bagi peserta didik, mampu mengembangkan potensi yang ada di dalam diri peserta didik. Sesuai dengan Undang-Undang R.I No.20 Tahun 2003 tentang Sistem Pendidikan Nasional Pasal 1 Ayat ( 1 ) menyatakan bahwa Pendidikan adalah usaha sadar dan terencana untuk mewujudkan suasana belajar dan proses pembelajaran agar peserta didik secara aktif mengembangkan potensi dirinya untuk memiliki kekuatan spritual, keagamaan, pengendalian diri, kecerdasan, akhlak, mulia serta keterampilan yang diperlukan dirinya, masyarakat, bangsa dan negara (Undang-Undang RI,2003: 3).

Tujuan pendidikan itu untuk menciptakan pribadi berkualitas dan memiliki karakter sehingga mempunyai visi yang luas kedepan untuk menggapai cita-cita yang diharapkan 
serta mampu beradaptasi efisien dalam berbagai lingkungan.Jadi salah satu konsep pendidikan itu sendiri adalah untuk sarana motivasi diri supaya menjadi lebih baik.

Istilah belajar sudah tidak asing lagi di telinga, karena secara tidak langsung dalam kehidupan dalam sehari-hari kita juga mengalami proses belajar meskipun proses belajar yang dilakukan berbeda dengan belajar di sekolah. Belajar adalah proses yang sangat manusiawi dan memiliki kedudukan yang sangat tinggi, baik dalam kehidupan masyarakat tradisional maupun modern. Belajar juga sering diartikan sebagai penambahan, perluasan,pendalaman pengetahuan, nilai dan sikap, serta keterampilan. Menurut Nana Syaodih dkk (2011:21) menjelaskan bahwa belajar adalah proses perubahan dalam kepribadian yang dimanifestasikan sebagai pola-pola respons yang baru berbentuk keterampilan, sikap, kebiasaan, pengetahuan, dan kecakapan. Kesimpulan bahwa belajar adalah suatu aktivitas yang dilakukan seseorang dengan sengaja dalam keadaan sadar untuk memperoleh suatu konsep, pemahaman, atau pengetahuan baru sehingga memungkinkan seseorang terjadinya perubahan perilaku yang relatif tetap baik dalam berfikir, merasa, maupun dalam bertindak.

Menurut Hamalik (2009:30), mengatakan hasil belajar adalah bila seseorang telah belajar akan terjadi perubahan tingkah laku pada orang tersebut, misalnya dari tidak tahu menjadi tahu, dan dari tidak mengerti menjadi mengerti. Sedangkan menurut
Dimyati dkk (2009:3), hasil belajar merupakan suatu interaksi tindak belajar dan tindak mengajar.

$$
\text { Menurut Sapriya }
$$

Pendidikan IPS adalah seleksi dari disiplin ilmu-ilmu sosial dan humaniora, serta kegiatan dasar manusia yang diorganisasikan dan disajikan secara ilmiah dan psikologi untuk tujuan pendidikan. Dengan demikian dapat disimpulkan bahwa pelajaran Ilmu Pengetahuan Sosial merupakan suatu pembelajaran yang berhubungan erat dengan kehidupan sosial, yang bertujuan agar peserta didik menjadi warga Negara yang baik, baik dalam lingkup keluarga, sekolah maupun dalam lingkup masyarakat.

Dalam mencapai proses pembelajaran dengan baik kita tidak luput dari suatu metode yang akan digunakan pada proses pembelajaran. Dengan tujuan untuk memberikan kemudahan pada proses penyampaian materi pelajaran dengan memberikan kemudahan untuk peserta didik memahami materi pelajaran. Metode pembelajaran dapat diartikan sebagai proses atau prosedur yang hasilnya adalah belajar atau dapat pula merupakan alat memenuhi makna belajar menjadi aktif. Dan lebih penting lagi adalah jika metode dapat dianggap sebagai suatu proses yang memungkinkan terjadinya belajar, mka metode tentu akan menjadi terdiri atas beberapa tahapan. Tahapan-tahapan yang dimaksud pada metode tertentu dapat pula digunakan pada metode menajar lainnya.

Silberman

(2010:12) mengemukakan

bahwa proses 
mempelajari sesuatu yang baru adalah lebih efektif jika peserta didik tersebut aktif mencari pola dari pada menerima saja (terus bertanya dari pada hanya menerima apa yang disampaikan oleh pengajar). Satu cara menciptakan pola mengajar yang aktif ini adalah merangsang peserta didik untuk bertanya tentang materi tanpa penjelasan dari pengajar terlebih dahulu. Metode sederhana ini merangsang siswa untuk bertanya. Metode Learning Start With a Question (LSQ) merupakan suatu metode pembelajaran yang merupakan bagian dari active Learning dikembangkan oleh Silberman. Kesimpulan Learning Start With a Question (LSQ) adalah suatu metode pembelajaran aktif dalam bertanya, maka peserta didik diminta untuk mempelajari materi yang akan dipelajari yaitu dengan membaca terlebih dahulu, dengan membaca maka peserta didik memiliki gambaran tentang materi yang akan dipelajari, sehingga apabila dalam membaca atau membahas materi tersebut terjadi kesalahan konsep akan terlihat dan dapat dibahas serta dibenarkan secara bersama- sama.

Pelajaran yang dimulai dengan pertanyaan Learning Start With a Question (LSQ), objek yang dimaksud di atas merupakan kondisi yang diberikan kepada pembelajar untuk menyusun pertanyaan tentang materi pembelajaran yang belum dimengerti. Kegiatan ini dapat melatih keterampilan berfikir kritis karena menyusun pertanyaan merupakan upaya mengembangkan rasa ingin tahu peserta didik dalam memperoleh berbagai informasi.

\section{METODE PENELITIAN}

Penelitian dilaksanakan dengan Penelitian Tindakan Kelas (PTK), karena penelitian ini merupakan suatu pencermatan terhadap kegiatan belajar berupa sebuah tindakan kelas, yang sengaja dimunculkan dan terjadi di dalam sebuah kelas secara bersama. Tindakan tersebut diberikan oleh guru atau dengan arahan dari guru yang dilakukan oleh peserta didik.

Menurut Diplan dan Andi Setiawan (2018:120) Penelitian Tindakan Kelas adalah penelitian yang dilakukan oleh guru dengan maksud untuk melihat kemampuan diri dan memperbaiki kualitas proses pembelajaran kelas, sehingga hasil belajar siswa dapat ditingkatkan, aktifitas belajar peserta didik menjadi semakin baik dan aktif. Sedanglan menurut Kunandar (2010:45) menyatakan bahwa PTK penelitian tindakan yang dilakukan dengan tujuan memperbaiki mutu praktik pembelajaran dikelas. PTK adalah studi yang dilakukan untuk memperbaiki diri sendiri, yang dilaksanakan secara sistematis,terencana,dan dengan sikap mawas diri.

Penelitian Tindakan Kelas adalah penelitian yang mencermati proses kegiatan belajar dengan menggunakan suatu metode pembelajaran dengan tujuan memperbaiki mutu praktik proses pembelajaran. 


\section{HASIL PEMBAHASAN}

\section{Aktivitas Belajar Peserta Didik Ketika Menggunakan Metode Pembelajaran Learning Start With a Question (LSQ)}

Hasil observasi belajar peserta didik berdasarkan pengamatan kedua observer yaitu guru mata pelajaran IPS dan teman sejawat bahwa skor aktivitas belajar peserta didik pada siklus I secara individual terdapat 15 orang peserta didik yang memperoleh skor $\geq 75$ dan 9 orang peserta didik yang memperoleh skor $<75$ dengan skor rata-rata 2,67, sehingga peserta didik pada siklus I belum bisa dikategorikan baik.

Skor aktivitas belajar peserta didik pada siklus II secara individual terdapat 23 orang peserta didik yang memperoleh skor $\geq 75$ dan 1 orang peserta didik yang memperoleh skor < 75 dengan skor rata-rata 3,86 sehingga aktivitas peserta didik pada siklus II sudah dapat dikategorikan baik.

2. Hasil Belajar Peserta Didik Setelah Menggunakan Metode Pembelajaran Learning Start With a Question (LSQ)

Hasil belajar IPS pada peserta didik kelas VII-A MTs Miftahul Jannah Palangka Raya stelah menggunakan metode pembelajaran Learning Start With a Question (LSQ) mengalami peningkatan.

Sesuai dengan data temuan hasil analisis keaktifan dan peningkatan hasil belajar peserta didik setelah dilakukan perbaikan dengan menggunakan metode pembelajaran Learning Start With a Question (LSQ), terbukti dapat mencapai hasil yang lebih baik dari sebelumnya. Dalam pelaksanaan peningkatan hasil belajar peserta didik pada pembelajaran IPS ini, terbukti telah terjadi peningkatan ketuntasan belajar secara klasikal awal yaitu $0 \%$ (tidak yang tuntas), menjadi 95,83 \% (23 orang) peserta didik yang tuntas.

\section{KESIMPULAN}

Berdasarkan hasil penelitian yang telah dibahas maka dapat disimpulkan beberapa hal yaitu:

1. Peningkatan aktivitas belajar ketika menggunakan metode pembelajaran Learning Start With A Question (LSQ) pad peserta didik kelas VII-A MTs Miftahul Jannah Palangka Raya menjadi lebih baik, yaitu skor aktivitas belajar peserta didik pada siklus I secara individual terdapat 15 orang peserta didik yang memperoleh skor $\geq 75$, dan 9 orang peserta didik yang memperoleh skor $75<$ dengan skor rata-rata 2,67. Skor aktivitas belajar peserta didik pada siklus II terdapat 23 peserta didik yang memperoleh skor $\geq 75$, dan 1 orang peserta didik yang 
memperoleh skor < 75 dengan skor rata-rata 3,86 , sehingga aktivitas belajar peserta didik pada siklus II sudah dikategorikan baik atau telah mencapai indikator keberhasilan.

2. Ada peningkatan hasil belajar IPS setelah menggunakan metode pembelajaran Learning Start With A Question (LSQ) pada peserta didik kelas VII-A MTs Miftahul Jannah Palagka Raya. Hal ini terlihat dari data hasil belajar peserta didik pada saat pre test memperoleh nilai rata- rata 30,20 dengan ketuntasan secara klasikal $0 \%$. Post test Siklus I memperoleh nilai rata-rata 78,95 dengan ketuntasan secara klasikal $62,5 \%$, dan pada siklus II meningkat dengan nilai rata-rata 90,41 dengan ketuntasan secara klasikal 95,83\%.

\section{DAFTAR PUSTAKA}

Dimyati dan Mudjiono. (2009). Belajar dan Pembelajaran. Jakarta: PT Rineka Cipta.

Diplan \& Andi Setiawan, M. (2018) Penelitian Tindakan kelas Yogyakarta: Deepublish.

Hamalik, Oemar. (2009). Proses Belajar Mengajar. Jakarta: Bumi Aksara.

Kunandar, 2010. Langkah Mudah Penelitian Tindakan Kelas Sebagai Pengembangan Profesi Guru Edisi Revisi. Jakarta: PT Raja Grafindo Persada

Nana Syaodih Sukmadinata. (2011). Landasan Psikologi Proses
Pendidikan. Bandung: Remaja Rosdakarya

Sapriya. (2012). Pendidikan IPS. Bandung: Remaja Rosdakarya.

Silberman, Melvin. (2010). Active Learning $101 \quad$ Strategi Pembelajaran Aktif. Yogyakarta: Yappendi.

Undang-Undang RI No.20 Tahun 2003

Tentang Sisdiknas. Yogyakarta: Media Abadi.

Tarwiyah* Mahasiswa FKIP UM Palangkaaraya

Setyo Wibowo** Dosen Universitas Muhammadiyah Palangkaraya 